\title{
KESAN FAKTOR TERMINOLOGI, SEMANTIK DAN 'URF DALAM PENGHURAIAN BERKAITAN ISU MAKANAN
}

\section{The Effect of Terminology, Semantics and Culture on the Interpretation of Food Issues}

\author{
Zainur Rijal Abdul Razak * \\ Wan Azura Wan Ahmad ** \\ Lubna Abdul Rahman*** \\ Arnida Abu Bakar $* * * *$
}

\begin{abstract}
The process of Quran interpretation actually requires a combination of knowledge of various disciplines. It is undeniable that the Arabic language factor is the branch of knowledge that must be considered when interpreting the Quranic verses. This is because the purpose of a particular interpretation of the Quran as a source of law should be construed in accordance with the views of Islamic scholars when influenced by language factors. The objective of this paper is to identify to what extent three factors, namely, Arabic terminology, semantics and 'urf, can affect the Quranic interpretation and hukum production of halal food issue. To achieve the objective, the library research
\end{abstract}

\footnotetext{
* Fakulti Pengajian Bahasa Utama, Universiti Sains Islam Malaysia, zrijalrazak@gmail.com

** Fakulti Pengajian Bahasa Utama, Universiti Sains Islam Malaysia, wanazura@usim.edu.my

*** Fakulti Pengajian Bahasa Utama, Universiti Sains Islam Malaysia, lubna@usim.edu.my

**** Fakulti Pengajian Bahasa Utama, Universiti Sains Islam Malaysia, arnida@usim.edu.my
} 
method was used to analyse related verses in surah al-Má'idah and al-An 'äm. The study found that there is a close relationship between terminology, semantics and 'urf with the interpretation and views of Muslim scholars on the issue of food in the Quran.

Keywords: Arabic Language, Terminology, Semantic, 'Urf, Hukm

\section{PENDAHULUAN}

Bahasa Arab telah mendapat kedudukan yang istimewa sebagai bahasa al-Quran. Pemilihannya sebagai bahasa al-Quran adalah tepat berdasarkan ciri-ciri keistimewaan yang sesuai dengan peranan yang dimainkan sebagai wadah penyebaran ajaran al-Quran yang dianggap agung dan mulia. Anwār al-Jundī menyenaraikan beberapa kelebihan utama bahasa Arab yang melayakkannya menjadi bahasa al-Quran. ${ }^{1}$ Antaranya adalah bahasa Arab merupakan bahasa yang paling hampir dengan ilmu mantik yang mana ungkapan-ungkapannya amat sesuai digunakan dalam apa jua keadaan. Selain itu, bahasa Arab juga memiliki kepelbagaian gaya bahasa dan cara penyampaian. Menurut Tawfĩq Muhammad Syahīn, bahasa Arab adalah bahasa yang paling luas dan kaya serta mempunyai banyak aliran. ${ }^{2}$

Sebagai kitab perundangan tertinggi bagi umat Islam, alQuran telah menjadi pegangan dan rujukan dalam segala aspek kehidupan manusia sama ada di dunia mahupun akhirat. Justeru, ramai para sarjana Islam semenjak zaman sahabat, tabiin dan generasi selepasnya telah mengkaji al-Quran dan mengistinbātkan hukum-hakam darinya mengikut kemampuan dan ketinggian ilmu yang dimiliki termasuklah ilmu bahasa Arab. ${ }^{3}$ Namun, pada zaman

\footnotetext{
Anwār al-Jundī, al-Fuṣhāa Lughah al-Qur'ān (Bayrūt: Dār al-Kitāb al-Lubnānī, 1982), 22.

2 Tawfīq Muhammad Syahīn, 'Awāmil Tanmiyyah al-Lughah al'Arabiyyah (Qāhirah: Maktabah Wahbah, 1980), 35.

3 Hussin Salamon, Mohd. Ismail Mustari, Ahmad Kilani Mohamad et. al, "Kajian Kesan Perbezaan Aliran Mazhab Ke Atas Kesatuan Masyarakat Islam," (Laporan Penyelidikan, Universiti Teknologi Malaysia, Skudai, 2003), 7.
} 
sahabat perbezaan pendapat dapat dielak kerana pada zaman itu para sahabat mengamalkan pendekatan syura dan mengambil keputusan ijtihād jamā' $\bar{l}$ apabila timbul sesuatu isu berkaitan hukum-hakam. ${ }^{4}$

Oleh kerana kemampuan, pengalaman dan latar belakang ulama yang berbeza, hukum yang diistinbāțan dari suatu ayat alQuran dalam suatu isu itu mungkin berlaku perbezaan. Walaupun berlaku kepelbagaian pandangan, para ulama telah menyandarkan hukum-hukum yang dikeluarkan kepada dalil dan hujah yang jelas. ${ }^{5}$ Dalam hal ini para ulama terkemudian dengan ilmu yang dimiliki mengambil pendekatan menyokong (mentarjīh) manamana pandangan yang bersesuaian dengan situasi semasa tanpa merendahkan pandangan yang tidak disokong. ${ }^{6}$ Perbezaan pendapat sebegini, dalam agama Islam, telah diterima sebagai kepelbagaian pendapat dalam mazhab-mazhab fiqh Islam dan tidak bercanggah dengan prinsip-prinsip Islam.

Antara faktor yang menjadi punca berlakunya kepelbagaian pandangan hukum dalam Islam khususnya dalam mengistinbāt hukum dari ayat-ayat al-Quran adalah faktor bahasa Arab itu sendiri di samping faktor 'urf atau budaya yang melingkari kehidupan seseorang ulama. ${ }^{7}$ Kepelbagaian hukum yang dipengaruhi oleh faktor bahasa Arab banyak dipengaruhi oleh aspek terminologi (istilah) dan semantik (makna). Setiap lafaz yang digunakan dalam al-Quran boleh dilihat dari pelbagai sudut. Ini akhirnya mengakibatkan kefahaman yang berbeza bagi sesuatu ayat yang dikaji dan berlakunya hukum yang berbeza. Justeru, kajian ini

4 Hussin, Mohd. Ismail, Ahmad Kilani et. al, "Kajian Kesan Perbezaan Aliran Mazhab", 5.

5 Mohd. Ramizu Abdullah@Zakaria, "Doktrin Sadd al-Dhara'i” dan Pemakaiannya dalam Pemerintahannya dalam Kerajaan Negeri Kelantan dari tahun 1990-1998" (Disertasi Sarjana, Universiti Malaya, Kuala Lumpur, 2001), 16.

6 Hussin, Mohd. Ismail, Ahmad Kilani et. al, "Kajian Kesan Perbezaan Aliran Mazhab", 7.

7 Noor Haslina Osman, "Adat Melayu Sebagai Sumber Hukum: Penilaian Dari Perspektif Teori al- 'Urf wa al- 'Ādah" (Tesis Sarjana, Universiti Malaya, Kuala Lumpur, 2004), 55; lihat juga Hussin, Mohd. Ismail, Ahmad Kilani et. al, "Kajian Kesan Perbezaan Aliran Mazhab", 7. 
dijalankan bertujuan untuk melihat, mengkaji dan mendedahkan hakikat bahawa sebahagian kepelbagaian hukum dalam ayat alQuran berkaitan isu makanan adalah disebabkan ketiga-tiga faktor ini iaitu terminologi, semantik dan 'urf.

\section{TINJAUAN LAMPAU}

Menurut pandangan Aḥmad Fahmī Abū Sinah, 'urf atau budaya bermaksud amalan seorang manusia atau kelompok masyarakat tertentu. ${ }^{8}$ Ia merupakan salah satu faktor penting dalam mengeluarkan hukum, ${ }^{9}$ seperti dalam isu makanan ini dan sebagainya. Antara syarat penerimaan 'urf sebagai sumber hukum sudah pasti mesti tidak bertentangan dengan prinsip-prinsip hukum Islam. ${ }^{10}$

Dari aspek bahasa iaitu terminologi dan semantik, 'Abd alKarīm Mujāhid menyatakan bahawa ahli bahasa dan usul fiqh amat menitikberatkan pengucapan perkataan dan ayat dari segi istilah dan maknanya. ${ }^{11}$ Kefahaman yang tepat dalam aspek ini amat diperlukan kerana ia menjamin ketepatan kefahaman ayat al-Quran dan seterusnya pengeluaran hukum. Sebahagian kepelbagaian hukum yang berlaku dalam aspek ini dipengaruhi oleh tahap penerimaan Qiraat berbeza oleh aliran-aliran mazhab nahu. ${ }^{12}$ Qiraat yang berbeza sebahagiannya menyebabkan timbulnya kepelbagaian interpretasi apabila sesuatu ayat itu menyentuh berkaitan hukum. Sebagai contoh, pemahaman ulama

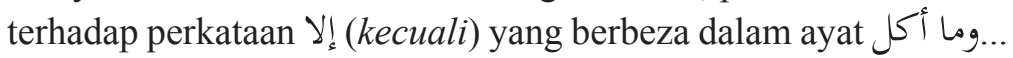
(binatang yang dimakan binatang buas kecuali sempat disembelih) menyebabkan berlakunya perbezaan hukum

8 Aḥmad Fahmī Abū Sinah, al- 'Urf wa al- 'Ādah fì Ra'y al-Fuqahā' (Qāhirah: Dār al-Bașā'ir, 2004), 8.

9 Hussin, Mohd. Ismail, Ahmad Kilani et. al, "Kajian Kesan Perbezaan Aliran Mazhab", 7.

10 Noor Haslina, “Adat Melayu Sebagai Sumber Hukum”, 70-72.

11 'Abd al-Karīm Mujāhid, al-Dilālah al-Lughawiyyah 'inda al- 'Arab (t. t. p: Dār al-Diyā', 1985), 9.

12 Ab. Halim Mohamad, "Perselisihan Mazhab Nahu Basrah dan Kufah dan Implikasinya Terhadap Pemahaman dan Penterjemahan Quran," Islamiyyat 27 (2007): 126-128. 
pegangan sama ada binatang yang sempat disembelih itu hanyalah binatang yang dimakan binatang buas sahaja atau semua kategori binatang yang disebutkan dalam ayat. ${ }^{13}$

Menurut Muhammad Marwan dan Wan Moharani, terdapat mazhab-mazhab tertentu dalam bahasa seperti yang terdapat dalam masalah fiqh Islam. Mazhab-mazhab ini juga sering berbeza pendapat terutama tentang tatabahasa Arab. ${ }^{14}$ Antara yang paling dikenali dan sering berlaku pertembungan pendapat dalam masalah bahasa adalah mazhab Kufah dan Basrah. ${ }^{15}$ Justeru, pegangan ulama fiqh kepada mazhab-mazhab bahasa yang tertentu menyebabkan berlakunya kepelbagaian pandangan dalam menghuraikan hukum dalam al-Quran. Selain itu, dalam bahasa Arab dan bahasa-bahasa lain di dunia, wujudnya ciri perkataan polisemi (lafaz musytarak) atau satu perkataan yang mempunyai dua maksud atau lebih. Contoh lafaz musytarak yang menyebabkan perbezaan hukum fiqh adalah perkataan qurü' dalam surah al-Baqarah ${ }^{16}$ ayat 228 yang membawa dua maksud dalam kalangan para ulama fiqh iaitu sama ada bermaksud haid atau masa suci. ${ }^{17}$ Kefahaman berbeza mengenai maksud perkataan ini menyebabkan perbezaan hukum mengenai tempoh masa bersuci bagi wanita yang datang haid.

Menurut Zainur Rijal dan lain-lain, faktor bahasa dan 'urf memainkan peranan yang penting dalam mempengaruhi kepelbagaian hukum dalam isu makanan di dalam al-Quran. ${ }^{18}$ Pandangan ini disokong oleh al-'Alwān̄i yang menyatakan

13 Perbincangan lanjut contoh ini terdapat pada bahagian perbincangan.

14 Muhammad Marwan Ismail \& Wan Moharani Mohammad, Kajian Tatabahasa Arab Dahulu Dan Sekarang (Nilai: Universiti Sains Islam Malaysia, 2008), 20.

15 Ibid, 21-22

16 Ayat (والمطلقات يتربصن بأنفسهن ثلاثة قروء. (...

17 Mahdī, Zayd 'Alī, "Suwar al-Musytarak al-Lafẓ̂̄ fī al-Qur'ān alKarīm wa Atharuhā fī al-Ma'nā," Jurnal Umm al-Qurā li 'Ulūm alSyarī'ah wa al-Dirāsat al-Islāmiyyah 54 (2011): 220.

18 Zainur Rijal Abdul Razak, Arnida Abu Bakar, Wan Azura Wan Ahmad et. al, "Kesan Bahasa Arab Terhadap Penghuraian Isu Makanan Dalam Surah al-Maidah dan Surah al-An'am: Kajian Dari Aspek Terminolgi, Semantik dan Budaya," Laporan Penyelidikan (Universiti Sains Islam Malaysia, Nilai, 2006), 3. 
bahawa aspek bahasa merupakan antara punca berlakunya perbezaan pandangan ulama dalam mengeluarkan hukum berkaitan makanan. ${ }^{19}$ 'Abd al-Wahhāb Țawīlah mendapati berlaku perbezaan pendapat dalam kalangan ulama dalam beberapa ayat alQuran berkaitan isu makanan. Antaranya, beliau mendapati istilah laḥm khinzīr (daging babi) yang dinyatakan dalam ayat berkaitan pengharaman memakan babi tidak terbatas kepada daging sahaja tetapi merangkumi semua anggota badan. ${ }^{20}$

\section{METODOLOGI}

Kajian ini menggunakan kaedah kajian perpustakaan dan analisa teks terhadap ayat-ayat al-Quran yang membincangkan tentang isu hukum makanan dalam surah al-Mā'idah dan surah al-An'ām. Kedua-dua surah ini dipilih kerana ia adalah antara surah yang paling banyak menceritakan tentang hukum makanan tertentu berbanding surah-surah lain. Namun, tidak semua ayat berkaitan makanan dalam dua surah ini dikaji, sebaliknya terhad kepada ayat-ayat yang mempunyai perbezaan pandangan ulama yang disebabkan oleh faktor bahasa dan 'urf tadi.

Bagi mendapatkan maklumat yang mencukupi, sumber maklumat diperluaskan. Bukan sahaja ke atas buku-buku ilmiah, penyelidikan dan jurnal, tetapi juga kepada maklumat-maklumat yang berautoriti di dalam internet. Ia mencakupi bahan-bahan dalam dua bidang utama dalam kajian ini iaitu bahasa Arab dan fiqh Islam. Pembentangan perbincangan dapatan kajian menggabungkan antara dua bidang bagi melihat pertalian terus kesan bahasa Arab terhadap pengeluaran hukum makanan dalam Islam.

\footnotetext{
19 TTaha Jābir Fayyāḍ al-'Alwānī, Adab Perbezaan Pendapat Dalam Islam (Kuala Lumpur: Dewan Pustaka Islam, 1989), 103.

20 'Abd al-Wahhāb 'Abd al-Salām Țawīlah. Athār al-Lughah fì Ikhtilāf al-Mujtahidīn (Qāhirah: Dār al-Salām, 2000), 198.
} 


\section{PENGERTIAN TERMINOLOGI, SEMANTIK DAN 'URF}

\section{a) Terminologi}

Perkataan terminologi dalam Bahasa Arab ialah musțalah atau iștilāhh. Selain itu, perkataan kalimah atau lafāz juga digunakan. Ia boleh dilihat dari dua sudut:

\section{Dari sudut bahasa}

Terminologi (iștilāh) berasal daripada perkataan șolaḥa (صلح) yang bermaksud baik atau bagus. ${ }^{21}$

\section{Dari sudut teknikal}

Ia bermaksud persepakatan sesuatu kumpulan terhadap sesuatu perkara yang khusus. Dalam cabang-cabang ilmu Islam, perkataan terminologi telah digunakan untuk membawa maksud perkataan yang dipersetujui penggunaannya oleh golongan pakar dalam sesuatu bidang tertentu untuk menunjukkan maksud tertentu dalam bidang tersebut seperti istilah ilmu hadis, ilmu sintaks, ilmu bahasa dan sebagainya. ${ }^{22}$ Menurut pakar-pakar bahasa Barat, terminologi bermaksud satu set perkataan teknikal atau satu pernyataan yang digunakan dalam subjek-subjek tertentu seperti terminologi perubatan, undang-undang dan lain-lain. ${ }^{23}$

\section{b) Semantik}

Semantik ialah satu cabang ilmu yang berkaitan dengan makna atau perubahan makna kata. Apabila Islam datang, banyak perubahan pada perkataan dan makna kata telah berlaku. Perubahan yang dimaksudkan ini boleh dibahagikan kepada empat cara iaitu:

21 A. W. Munawwir, Kamus al-Munawwir Arab-Indonesia (Indonesia: Pustaka Progressif, 2002), 788-789.

22 Nūr al-Hudā Lūsyan, "Isykāliyyah al-Mușțalạ̣ bayna al-Naẓāriyyah wa al-Tațbīq," al-Tajdīd 16 (2004): 147.

23 A S Hornby, Oxford Advanced Learner's Dictionary (Oxford University Press, 2005), 1583. 
1. Menghapuskan lafaz-lafaz Arab jahiliyyah yang bertentangan dengan sifat atau ruh al-Quran, contohnya, penggunaan lafaz "خبثت نفسي". Begitu juga dengan istilah-istilah yang baik

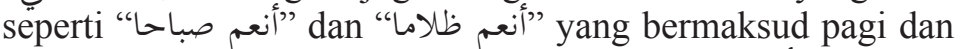
malam yang baik yang telah diganti dengan " لكيف أصبحتم" dan "كيف أمسيتم"

2. Memindahkan makna lafaz yang bersifat hissī kepada bersifat ma 'nawī seperti perkataan "ب," yang membawa makna tuan atau raja telah berubah kepada makna yang dikhususkan untuk tuhan atau Allah yang mentadbir setiap sesuatu.

3. Memperbaharui lafaz-lafaz yang berkaitan dengan ajaran dan syiar Islam yang disebut dengan al-alfāz al-Islāmiyyah, seperti al-șalāh, al-masjid dan al-'aqīdah.

4. Mewujudkan al-tarkīb al-Islāmì dengan menyandarkan perkataan yang terdapat dalam bahasa Arab kepada perkataan seperti Islam, Muslimin, Allah. Contohnya ungkapan assalāmu'alaykum yang terdapat perkataan Islam atau salam di dalamnya, sayf Allāh, ikhwān al-muslimīn dan sebagainya.

\section{'URF (BUDAYA)}

'Urf adalah perkataan yang membawa maksud budaya. Dari sudut bahasa (lughaw $\vec{l}$ ) 'urf berasal daripada perkataan (عرف) yang bermaksud mengetahui, atau apa yang telah diketahui, atau sesuatu yang dikerjakan. Manakala, pengertian budaya mengikut istilah pula menjelaskan bahawa budaya merupakan sesuatu perbuatan atau perkataan yang telah menjadi satu kebiasaan dan diterima pakai oleh golongan tertentu. ${ }^{24}$ Ia merupakan satu manifestasi dari amalan seharian masyarakat yang sudah menjadi satu adat dan kebiasaan yang sudah sukar untuk diubah. 'Urf, menurut pandangan ahli fiqh Islam, dianggap sebagai salah satu sumber yang penting dalam perundangan Islam (Syarīah Islämiyyah)

24 Hasanayn, Maḥmūd Hasanayn, al-'Urf wa al-'Ādah bayna alSyarì'ah al-Islāmiyyah wa al-Qānūn al-Wạ̣ 'ì (Dubai: Dār al-Qalam, 1988), 13. 
kerana peranannya dalam menyelesaikan masalah-masalah mendatang yang kadang-kadang tidak diduga.

\section{DAPATAN DAN PERBINCANGAN}

Terdapat lebih kurang 10 ayat dalam surah al-Mā'idah yang membincangkan isu makanan secara langsung dan 9 ayat dalam surah al-An'ām. Namun, apabila dikaitkan dengan ketiga-tiga faktor yang dikaji iaitu terminologi, semantik dan 'Urf, hanya sebahagian dari ayat-ayat ini memperlihatkan kesan ketiga-tiga faktor ini.

\section{a) Surah al-Mā'idah}

\section{Ayat ke-3}

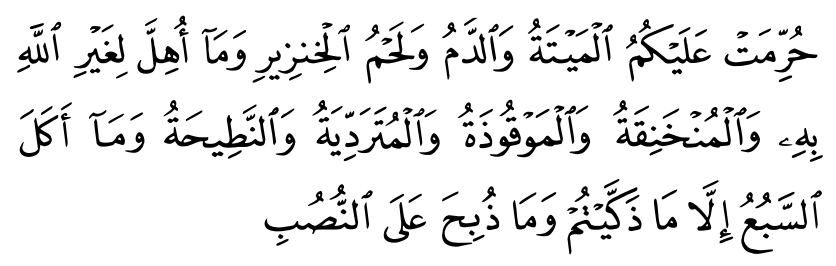

Maksudnya: Diharamkan bagi kamu bangkai dan darah dan daging babi dan apa-apa yang disembelih untuk yang selain Allah, dan yang mati tercekik, dan yang mati terpukul, dan yang mati terjatuh, dan yang kena tanduk dan yang dimakan binatang buas, kecuali yang sempat kamu sembelih; dan yang disembelih atas Nusub...

Antara bahagian ayat yang dipengaruhi oleh ketiga-tiga faktor ini ialah:

\section{1. 'Diharamkan ke atas kamu bangkai'}

Ayat di atas dari segi semantiknya membawa maksud hukum haram ke atas orang-orang Islam dalam perkara-perkara yang 
dinyatakan selepasnya. Didapati bahawa pengharaman ini adalah berbentuk umum iaitu sama ada pengharaman memakannya, menggunakannya, memakai dan apa jua bentuk manfaat yang boleh diperolehi. Dalam menghuraikan maksud perkataan 'diharamkan' ini, para ulama telah mengaitkannya dengan faktor bahasa Arab iaitu Iqtid̄à' (الاقتضاء). Maksud Iqtid̄à' ialah perkataan yang membawa maksud keluar dari makna zahir dan perlu dita 'wilkan bersesuaian dengan kehendak syarak dan akal. ${ }^{25}$ Merujuk kepada ayat di atas didapati bahawa terdapat perkataan yang tidak dizahirkan dan menjadi mudāf (sandaran) kepada perkataan bangkai iaitu 'memakan'.

Dalam tatabahasa Arab, pembuangan atau penyingkiran mudāf (sandaran) memang perkara yang biasa berlaku, contohnya ayat al-Quran: itu'. Mudāf yang dibuang di sini ialah 'penduduk' kerana secara logiknya sesuatu kampung tidak mungkin ditanya dan menjawab, tetapi 'penduduknya'. ${ }^{27}$ Situasi yang sama berlaku dalam ayat dalam surah al-Mā'idah ini apabila didapati bahawa mudā $f$ yang dibuang itu adalah perkataan 'memakan'. ${ }^{28}$ Ia dibuktikan dengan wujudnya perkataan 'daging' pada perkataan babi yang biasanya dimanfaatkan untuk dimakan serta ayat selepas itu yang bermaksud 'kecuali yang sempat disembelih'. Ini kerana lazimnya penyembelihan binatang dilakukan bertujuan untuk dimakan.

\section{2. 'Kecuali sempat disembelih'}

Pengaruh faktor semantik pada perkataan 'kecuali' (istithna ') dalam ayat ini memberi kesan kepada penghuraian hukum memakan daging binatang. Berlaku perbezaan pendapat dalam kalangan ulama tentang semantik huruf istithnā' ini, adakah ia membawa makna penghubung atau pemisah? Begitu juga dalam tatabahasa Arab, perkara yang sama berlaku iaitu huruf istisna ${ }^{\text {, }}$

\footnotetext{
25 'Abd al-Wahhāb Ṭawīlah, Athar al-Lughah, 312.

26 Surah Yūsof, 82.

27 'Abd al-Ḥamīd Sayyid Ṭalab, Tahzīb al-Naḥwī (Qāhirah: t.p.,1991), 297.

28 Al-Khațīb al-Qazwīnī, al-Ị̇̂ăh fì 'Ulūm al-Balāghah (Qāhirah: Mu'assasah al-Mukhtār, 1999), 145.
} 
sebagai pemisah dan penghubung. ${ }^{29}$ Contoh istithna $\bar{a}$ ' sebagai penghubung ialah حضر الطلاب إلا محمدا. Manakala contoh pemisah pula ialah:

Sebagai kesan daripada faktor semantik dalam huruf istithna ${ }^{\text {' }}$ ini, berlakulah perbezaan pendapat terhadap isu makanan dalam kalangan ulama fiqh pada ayat ini. Ulama yang berpendapat bahawa huruf istithn $\bar{a}$ ' ini membawa makna 'penghubung' mengatakan bahawa apa yang diharamkan sebelum huruf istithna ' 'menjadi halal apabila didapati binatang itu masih hidup dan sempat disembelih. Mereka berpendapat bahawa, pengecualian atau kelonggaran ini adalah merujuk kepada beberapa jenis binatang sahaja yang pada asalnya dihalalkan tetapi menjadi haram oleh sebab tertentu. Ini secara tidak langsung mengeluarkan beberapa jenis makanan yang disebutkan dalam ayat kerana tiada kaitan dengan pengecualian kepada 'sempat disembelih' iaitu bangkai, darah, daging babi dan binatang yang disembelih bukan dengan nama Allah.

Oleh itu, menurut pendapat Ibn 'Abbās, jenis-jenis binatang yang menjadi pokok persoalan frasa "kecuali sempat disembelih' dalam ayat ini ialah: binatang yang mati tercekik, dipukul, terjatuh, ditanduk dan binatang yang mati dimakan binatang buas. Sementara ulama lain berpendapat bahawa pengecualian ini hanya untuk binatang yang mati dimakan binatang buas sahaja kerana kedudukannya paling hampir dengan huruf istithnā' 'itu.

Manakala para ulama yang menyatakan bahawa huruf istithnn $\bar{a}$, ini membawa makna 'pemisah' berpendapat bahawa, apa yang diharamkan sebelum huruf istithn $\bar{a}$ ' tiada kaitan dengan perkara yang dikecualikan itu. Menurut mereka, tiada kaitan antara perkara yang dijelaskan sebelum huruf istithna $\bar{a}$ ' dan selepasnya kerana masing-masing mempunyai hukum yang tersendiri. Oleh itu, ayat ini boleh difahami bahawa binatang-binatang yang disembelih selain daripada apa yang telah disebutkan sebelum huruf istithn $\bar{a}$, adalah halal dimakan. ${ }^{31}$ Ini bermakna, binatang-binatang yang disebutkan sebelum huruf istithn $\bar{a}$ ' itu adalah haram dimakan sama

29 Ibn 'Aqīl, Bihā' al-Dīn 'Abd Allāh, Syarh Ibn 'Aqūl 'alā Alfiyyah Ibn Mālik (Bayrūt: al-Maktabah al-'Așriyyah, 1998), 546.

30 'Abd al-Hamīd Sayyid Țalab, Tahzīb al-Nahwwī, 124.

31 Muhammad 'Alī al-Șabūn̄̄, Rawā'i' ' al-Bayān, Tafsir Ayat-Ayat Hukum (Semarang: asy-Syifa', 1993), 373-374. 
sekali kerana ia telah menjadi bangkai dan tidak timbul persoalan sempat disembelih atau tidak.

\section{Ayat ke-4}

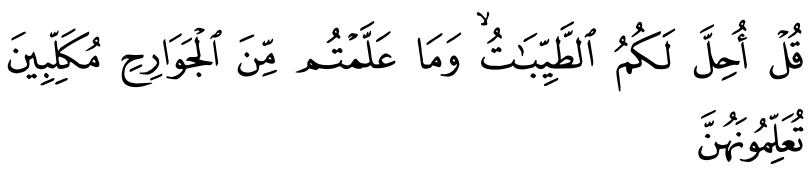

Maksudnya: Katakanlah, telah dihalalkan bagi kamu yang baik-baik, dan apa yang kamu ajar dari binatang-binatang penangkap, padahal telah kamu biasakan mereka berburu, yang kamu ajar mereka.

Dari segi terminologi perkataan mukallibin membawa erti binatang dari golongan anjing dan terbit dari perkataan kalb. ${ }^{32}$ Menurut Ibn Manẓūr, mukallib dari segi terminologi membawa maksud semua binatang buas yang digunakan untuk berburu. ${ }^{33}$ Jumhur ulama berpendapat bahawa yang dimaksudkan dengan mukallibinn ini adalah umum kepada semua jenis binatang yang boleh diajar asalkan menepati syarat-syarat tertentu. Mereka juga berpendapat bahawa penggunaan perkataan kilāb yang bermaksud 'anjing' adalah dipengaruhi oleh faktor 'urf kerana kebiasaan masyarakat Arab menggunakan anjing untuk berburu serta mengqiyaskan penggunaan binatang lain untuk berburu mengikut kebiasaan sesuatu tempat itu. ${ }^{34}$

Sementara sebahagian ulama lain pula berpendapat bahawa hanya anjing sahaja boleh diajar berburu. Manakala makanan hasil dari buruan selain anjing tidak halal untuk dimakan. Dari perbincangan ini jelas menunjukkan bahawa kesan terminologi dan urf memainkan peranan penting dalam menghuraikan isu binatang yang boleh dijadikan binatang buruan. Walaupun dari

32 Ibrāhīm An̄̄s, 'Ațiyyah al-Sawālihi, 'Abd al-Halīm Manșūr \& Muḥammad Ḥalf Allāh Aḥmad, al-Mu jam al-Wasìt (Qāhirah: Majma' al-Lughah al-‘Arabiyyah, 1972), 2 : 794.

33 Ibn Manz̄ūr, Lisān al- 'Arab (Qāhirah: Dār al-Hadīth, 2003), 7: 705.

34 Hamka, Abdul Malik Abdul Karim Amrullah, Tafsir al-Azhar (Singapura: Pustaka Nasional Pte. Ltd., 1999), 3 : 1631. 
segi terminologinya merujuk kepada anjing tetapi maksud sebenar yang dikehendaki dari ayat ini ialah semua jenis binatang yang boleh dilatih. Begitu juga dengan faktor urf yang mempengaruhi penghuraian ayat ini yang mana penggunaan apa jua jenis binatang untuk berburu dibolehkan mengikut kebiasaan sesuatu tempat selagi tidak ada larangan penggunaannya.

\section{Ayat ke-90}

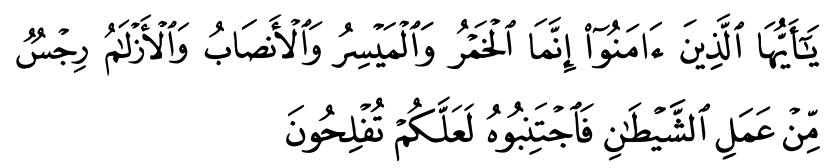

Maksudnya: Wahai orang-orang yang beriman! Bahawa sesungguhnya arak, judi, pemujaan berhala dan mengundi nasib dengan batang-batang anak panah, adalah (semuanya) kotor (keji) dari perbuatan Syaitan. Oleh itu hendaklah kamu menjauhinya supaya kamu berjaya.

Al-khamr dari sudut terminologi bermaksud sesuatu yang memabukkan yang diperbuat daripada air anggur dan lain-lainnya. Para ulama berpendapat bahawa al-khamr bermaksud setiap minuman yang menimbulkan dan menyebabkan mabuk. ${ }^{35}$ Imam Hanafi pula menjelaskan, al-khamr dikenali dalam kalangan orang Arab sebagai minuman yang diperbuat daripada air anggur sahaja kerana menurut mereka tidak berlaku qiyas dalam bahasa. Namun, pendapat ini disangkal oleh para ulama yang lain dengan mengatakan bahawa al-khamr dinamakan untuk semua minuman yang memabukkan dan boleh menguasai pemikiran seseorang serta menghilangkan kewarasannya.

Walau bagaimana pun, skop pengharaman arak ini sebenarnya lebih luas berdasarkan kepada tafsiran para ulama dan hadishadis Nabi. Pengharaman arak bukan hanya dengan meminumnya tetapi juga membelinya kerana para ulama juga bersepakat bahawa membeli arak juga adalah haram hukumnya, namun tidak termasuk menyentuh atau memegangnya. Sekiranya ditinjau

35 Hamka, Tafsir al-Azhar, 1861. 
dari jenis sumber yang boleh menghasilkan arak, kita dapati penghasilannya adalah mengikut 'urf sesebuah tempat. Di Asia, contohnya Indonesia dan Malaysia, arak juga boleh dihasilkan daripada nira yang diambil dari pohon nipah, atau dihasilkan daripada beras pulut yang diperam dan sebagainya. Manakala di Jepun pula, arak boleh dihasilkan daripada saringan beras. Dengan ini dapat disimpulkan bahawa, faktor terminologi tentang khamr telah mempengaruhi kepelbagaian hukum pengharamannya. Selain itu, sumber penghasilan khamr itu tidak semestinya dari anggur seperti kelaziman di Negara Arab, asalkan ia memabukkan dan boleh menghilangkan kewarasan akal peminumnya walaupun dihasilkan dari bahan lain seperti beras di Jepun dan nira di Asia.

\section{Ayat ke-96}

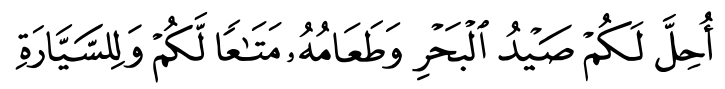

Maksudnya: Dihalalkan bagi kamu binatang buruan laut, dan makanan yang didapati dari laut, sebagai bekalan bagi kamu (untuk dinikmati kelazatannya) dan juga bagi orang-orang yang dalam pelayaran.

Perkataan yang menjadi pokok perbincangan di sini ialah (ليد) iaitu binatang buruan laut dan makanan yang didapati daripada laut. Didapati bahawa penerangan al-Quran dalam soal ini adalah secara umum yang akhirnya membawa kepada penafsiran yang pelbagai dalam kalangan ulama. Persoalan yang timbul ialah apakah semua jenis buruan laut dan makanan yang terdapat di dalamnya boleh dimakan. Faktor penerangan secara umum ini dikenali dalam bahasa Arab sebagai mujmal. Takrif mujmal dari segi istilah ialah perkataan yang tidak jelas maksudnya disebabkan berlaku kesamaran antara dua maksud atau lebih serta memerlukan kepada penjelasan. ${ }^{36}$ Ciri mujmal yang mengunakan kaedah penerangan secara umum mempengaruhi maksud sesuatu perkataan atau frasa dari segi semantiknya. Oleh yang demikian, berlaku pelbagai penghuraian dalam kalangan ulama.

36 'Abd al-Wahhāb Ṭawīlah. Athar al-Lughah, 297. 
Para ulama berpendapat bahawa semua binatang yang hidup sepenuhnya dalam laut atau dalam air walau apa pun namanya adalah halal dimakan termasuklah ikan, udang, sotong, ketam dan lain-lain. Ini kerana binatang tersebut dianggap elok oleh orang Arab. ${ }^{37}$ Namun begitu, menurut Imam Syafii, ikan lumba-lumba dan ikan jerung tidak harus dimakan kerana mempunyai taring. Manakala, bagi binatang dua alam, iaitu yang hidup di darat dan juga dalam air pula adalah haram dimakan mengikut pendapat Imam Syafii, seperti ketam batu, buaya, biawak, katak dan seumpamanya. Imam Malik pula berpendapat bahawa binatangbinatang ini tidak haram dimakan tetapi makruh kecuali katak yang boleh dimakan menurut mazhab tersebut kerana ia tergolong dalam buruan laut atau dikategorikan sebagai ikan dan haiwan yang tinggal dalam air. ${ }^{38}$

Kesimpulan daripada ayat ini ialah kepelbagaian penghuraian oleh ulama tentang maksud semantik frasa 'buruan dan makan laut' telah memberikan impak kepada hukum memakan makananmakanan tersebut. Ia berlaku disebabkan oleh ayat yang menerangkan situasi ini datang secara mujmal. Selain itu, aspek 'urf juga sedikit sebanyak memainkan peranan apabila para ulama menjadikan pandangan orang Arab sebagai penanda aras kepada penentuan halal haram sesuatu makanan. Ini membuktikan bahawa faktor bahasa khususnya faktor semantik dan 'urf mempengaruhi penghuraian ulama dalam isu makanan.

\section{b) Surah al-An'ām}

\section{Ayat ke-118}

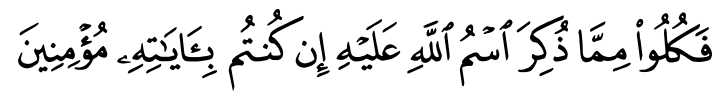

Maksudnya: Maka makanlah dari apa yang disembelih dengan menyebut nama Allah atasnya, jika memang kamu beriman kepada ayat-ayatNya.

37 Zulkifli Mohamad al-Bakri, Hukum Makan Katak dan Berubat Dengannya (Kajang: Dar al-Fuqaha', 2005), 11.

38 Hamka, Tafsir al-Azhar, 1883. 
Dalam Tafsir al-Azhar terdapat penghuraian makna yang luas dari sudut semantik mengenai "dari apa yang disembelih" iaitu binatang ternakan atau binatang buruan yang telah dihalalkan oleh agama Islam memakannya. Binatang-binatang tersebut perlulah disembelih terlebih dahulu dengan menyebut nama Allah. Begitu juga dengan maksud di sebalik ayat "Menyebut nama Allah atasnya." Allah telah menetapkan bahawa yang dimaksudkan dengan nama Allah itu ialah pertama: dengan melafazkan basmalah secara lengkap ketika binatang tersebut disembelih. Atau kedua: dengan menyebut "Bismillah (dengan nama Allah). Terdapat faktor tertentu di sebalik penetapan tentang penyembelihan ini. Hanya dengan menyebut nama Allah sahaja binatang sembelihan itu boleh dimakan. Manakala jika ia binatang ternakan atau buruan halal disembelih tetapi tujuannya untuk upacara penyembahan berhala atau pemujaan maka ia tidak halal lagi dimakan. Ini dibuktikan dengan jelas dalam firman Allah di penghujung ayat ini: "Jika memang kamu beriman kepada ayatayat-Nya". Ini bermakna hanya orang yang beriman dengan kitabNya dan rasul-Nya sahaja yang patuh kepada penetapan ini dan bagi orang-orang kufur serta tidak beriman, akan merasakan tiada bezanya memakan binatang sembelihan sama ada yang disebut dengan nama Allah, nama syaitan atau dengan nama berhala.

Ini bermakna hanya orang yang beriman dengan Allah sahaja yang patuh kepada penetapan ini. Bagi orang-orang kufur serta tidak beriman, mereka merasakan tiada bezanya memakan binatang sembelihan sama ada disebut dengan nama Allah, atau nama syaitan atau berhala.

\section{Ayat ke-145}

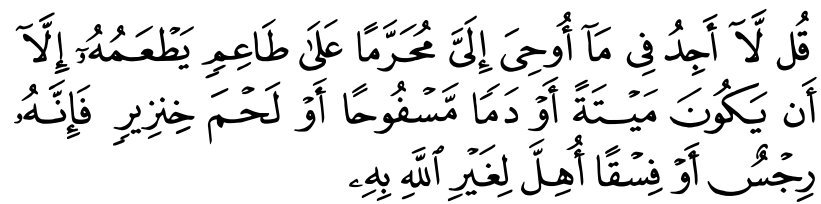

Maksudnya: Tiadalah aku peroleh dalam wahyu yang diwahyukan kepadaku, sesuatu yang diharamkan bagi orang yang hendak memakannya, kecuali kalau makanan itu bangkai, atau darah yang mengalir atau 
daging babi kerana sesungguhnya semua itu kotor atau binatang yang disembelih atas nama selain Allah.

\section{i) Mayyitah (bangkai)}

Dalam penghuraian perkataan ini, budaya memainkan peranan penting. Menurut Wahbah al-Zuhaylī, kriteria dalam penilaian baik buruk sesuatu makanan boleh berasaskan kepada selera bangsa Arab dalam Mazhab Syafii dan Hanbali. ${ }^{39}$ Hal ini dapat dilihat melalui pendapat yang dipegang oleh golongan Imam Syafii berdasarkan hadis Nabi SAW yang berbunyi "Semua yang dianggap kotor oleh bangsa Arab, hukumnya haram." Mereka menyatakan bahawa semua binatang yang tidak dijelaskan dalam nas halal atau haramnya, tidak pula ada suruhan atau larangan membunuhnya, apabila bangsa Arab menganggapnya baik, maka hukumnya halal. Apabila mereka menyatakannya kotor, maka hukumnya haram. Menurut Zulkifli Mohamad al-Bakri, penentuan hukum halal atau haram sesuatu binatang berdasarkan kepada kebiasaan orang Arab digunapakai kerana mereka merupakan golongan pertama menerima wahyu dan syariat Ilahi. ${ }^{40}$

\section{ii) Laḥm al-khinż̄r (daging khinzir)}

Perkataan laḥm al-khinzīr (daging khinzir) membawa maksud lemak, urat, kulit dan lain-lain. Sebaliknya, apabila kita menyebut perkataan lemak, urat atau kulit, maka ia tidak membawa maksud daging. Dari sudut bahasa Arąb, kata ganti nama - $h u$ (dia atau ia lelaki) dalam perkataan يَطَعَمُ mempunyai pelbagai penafsiran terhadap pemilik kata ganti nama tersebut. Sebahagian ulama misalnya al-Māwardī dan Ibn Ḥazm menyatakan bahawa ia adalah kata ganti nama bagi khinzir kerana haiwan tersebut adalah kata nama yang terdekat sekali disebutkan oleh Allah dalam ayat ini. Dakwaan ini disokong dengan menyatakan bahawa pengharaman terhadap khinzir bukan sahaja kepada dagingnya malah terhadap

\footnotetext{
39 Wahbah al-Zuhaylī, al-Fiqh al-Islāmī wa Adillatuh (Dimasyq: Dār al-Fikr, 1997).

40 Zulkifli Mohamad, Hukum Makan Katak dan Berubat Dengannya, 11.
} 
keseluruhan tubuh binatang tersebut seperti lemak, rambut, tulang dan juga kukunya.

Menurut sesetengah pendapat ulama, kata ganti nama ini dikembalikan kepada 'daging' dan bukannya khinzir. Dalam kaedah bahasa Arab, bagi perkataan mudāf dan mudāa ilayh, seandainya kedua-dua perkataan ini boleh berdiri secara berasingan, perkataan pertama iaitu al-mudāf tetap menjadi keutamaan dan bukannya mudāf ilayh kerana ia sekadar ikutan. Justeru, dalam ayat ini dapatlah disimpulkan bahawa perbincangan sebenarnya adalah terhadap perkataan daging dan bukannya khinzir. Manakala menurut 'Abd al-Wahhāb Tawīlah, perkataan 'daging' di sini bukanlah merujuk kepada daging semata-mata, malah termasuk juga kuku, tulang atau sebagainya. Perkataan daging digunakan kerana daging merupakan komponen utama binatang apabila melibatkan isu pemakanan dan menjadi tumpuan sesuatu perbincangan mengenainya ${ }^{41}$

\section{KESIMPULAN}

Semua ayat dari surah al-Mā'idah dan surah al-An'ām berkaitan makanan yang dijelaskan di atas menunjukkan hubungan yang begitu rapat antara penghuraian ayat-ayat al-Quran dengan ketiga-tiga faktor yang disentuh iaitu terminologi, semantik dan 'urf (budaya) khususnya dalam mengeluarkan hukum. Ini kerana, kebanyakan ayat-ayat al-Quran, khususnya yang melibatkan hukum-hakam, hanya menjelaskan secara ringkas dan menyentuh perkara-perkara dasar. Oleh itu, manusialah yang akan menafsirkannya mengikut kemampuan akal fikiran masingmasing dengan berpandukan sumber-sumber yang ada. Situasi ini menyebabkan wujudnya penghuraian yang berbeza dalam kalangan ulama dan hukumnya terhadap sesuatu ayat yang dibincangkan. Ini berlaku kerana setiap ulama mempunyai pandangan, tahap pemikiran dan aspek tumpuan yang berbeza.

Hakikatnya al-Quran yang bersifat ringkas bukanlah menjadi satu kecacatan kepadanya. Bahkan keistimewaannya tidak dapat ditandingi oleh mana-mana kitab lain atau sebarang karya kerana ia padat dan sempurna, mencakupi semua aspek kehidupan manusia.

41 'Abd al-Wahhāb Ṭawīlah, Athar al-Lughah, 137-138. 
Malah dapat membuka ruang kepada manusia mengeluarkan pendapat dan pandangan masing-masing.

Selain itu, pendapat yang pelbagai dalam kalangan ulama tidak harus dijadikan alasan untuk menjamah apa jua jenis makanan yang terhidang di depan mata. Sebaliknya makanan itu mesti diselidiki terlebih dahulu mengikut kemampuan kita. Kesimpulannya, dalam usaha memahami penghuraian ulama berkaitan isu makanan dalam al-Quran banyak aspek yang mesti diambil kira. Ini termasuklah faktor bahasa Arab seperti terminologi dan semantik begitu juga budaya, masa dan tempat.

Oleh itu, dalam memahami dan menghuraikan sesuatu ayat al-Quran seseorang itu perlu merujuk kepada banyak aspek dan bidang berkaitan bagi memperoleh pemahaman yang tepat dan bersesuaian dengan kehendak syarak. Semua pendapat ulama dahulu dan kini mesti diambil kira tanpa rasa ta'sub kepada manamana pendapat secara membuta tuli. Dengan itu persetujuan akan dapat dicapai antara semua pihak dan seterusnya memberikan pemahaman yang jelas kepada masyarakat awam.

\section{RUJUKAN}

Ab. Halim Mohamad. "Perselisihan Mazhab Nahu Basrah dan Kufah dan Implikasinya Terhadap Pemahaman dan Penterjemahan Quran.” Islamiyyat 27 (2007): 123-148.

'Abd al-Ḥamīd Sayyid Ṭalab. Tahzīb al-Naḥwī. Qāhirah: t. p., 1991.

'Abd al-Karīm Mujāhid. Al-Dilālah al-Lughawiyyah 'inda al'Arab. T.t.p.: Dār al-Diyā', 1985.

'Abd al-Wahhāb 'Abd al-Salām Țawīlah. Athar al-Lughah fì Ikhtilāf al-Mujtahidīn. Qāhirah: Dār al-Salām, 2000.

Abū Sinah, Ahmad Fahmī. Al- 'Urf wa al- 'Ādahfì Ra'y al-Fuqahà'. Qāhirah: Dār al-Bașā’ir, 2004.

Al-Alwān̄̄, Țaha Jābir Fayyāḍ. Adab Perbezaan Pendapat Dalam Islam. Kuala Lumpur: Dewan Pustaka Islam, 1989. 
Al-Jundī, Anwār. Al-Fuṣhāa Lughah al-Qur'ān. Bayrūt: Dār alKitāb al-Lubnān̄̄, 1982.

Al-Qazwīn̄i, al-Khațīb. Al-Ị̣̇̂h fì 'Ulūm al-Balāghah. Qāhirah: Mu'assasah al-Mukhtār, 1999.

Al-Șābūn̄̄, Muhạmmad 'Alī. Rawā'i' al-Bayān, Tafsir Ayat-Ayat Hukum. Semarang: asy-Syifa’, 1993.

A S Hornby. Oxford Advanced Learner's Dictionary. Oxford University Press, 2005.

A.W. Munawwir. Kamus al-Munawwir Arab-Indonesia. Indonesia: Pustaka Progressif, 2002.

Ibn 'Aqīl, Bihā' al-Dīn 'Abd Allāh. Syarh Ibn 'Aqūl 'alā Alfyyyah Ibn Mālik. Bayrūt: al-Maktabah al-'Așriyyah, 1998.

Ibn Manẓūr. Lisān al- 'Arab. Qāhirah: Dār al-Ḥadīth, 2003.

Ibrāhīm Anīs, 'Ațiyyah al-Sawālihi, 'Abd al-Ḥalīm Manșūr \& Muḥammad Half Allāh Aḥmad. Al-Mu'jam al-Wasịt. Qāhirah: Majma’ al-Lughah al-'Arabiyyah, 1972.

Hamka, Abdul Malik Abdul Karim Amrullah. Tafsir al-Azhar. Singapura: Pustaka Nasional Pte. Ltd., 1999.

Hasanayn, Maḥmūd Ḥasanayn. Al-'Urf wa al-'Ādah bayna alSyarī'ah al-Islāmiyyah wa al-Qānūn al-Waḍ 'ì. Dubai: Dār al-Qalam, 1988.

Hussin Salamon, Mohd. Ismail Mustari, Ahmad Kilani Mohamad et. al. "Kajian Kesan Perbezaan Aliran Mazhab Ke Atas Kesatuan Masyarakat Islam." Laporan Penyelidikan. Universiti Teknologi Malaysia, Skudai, 2003.

Mahdī, Zayd 'Alī. "Suwar al-Musytarak al-Lafẓ̄i fī al-Qurān alKarīm wa Atharuhā fī al-Ma'nā." Jurnal Umm al-Qurā li 'Ulūm al-Syarī'ah wa al-Dirāsāt al-Islāmiyyah 54 (2011): 208-239.

Mohd. Ramizu Abdullah@Zakaria. "Doktrin Sadd al-Dhara'i" dan Pemakaiannya dalam Pemerintahannya dalam Kerajaan 
Negeri Kelantan dari tahun 1990-1998." Disertasi Sarjana. Universiti Malaya, Kuala Lumpur, 2001.

Muhammad Marwan Ismail \& Wan Moharani Mohammad. Kajian Tatabahasa Arab Dahulu Dan Sekarang. Nilai: Universiti Sains Islam Malaysia, 2008.

Noor Haslina Osman. "Adat Melayu Sebagai Sumber Hukum: Penilaian Dari Perspektif Teori al- 'Urf wa al- 'Ādah." Tesis Sarjana. Universiti Malaya, Kuala Lumpur, 2004.

Nūr al-Hudā Lūsyan. "Isykāliyyah al-Mușțalah bayna alNaẓariyyah wa al-Taṭbīq". Al-Tajdīd 16 (2004): 147.

Tawfīq Muḥammad Syahīn. 'Awāmil Tanmiyyah al-Lughah al'Arabiyyah. Qāhirah: Maktabah Wahbah, 1980.

Wahbah al-Zuhaylī. al-Fiqh al-Islāmī wa Adillatuh. Dimasyq: Dār al-Fikr. 1997.

Zainur Rijal Abdul Razak, Arnida Abu Bakar, Wan Azura Wan Ahmad et. al. "Kesan Bahasa Arab Terhadap Penghuraian Isu Makanan dalam Surah al-Maidah dan Surah al-An'am: Kajian dari Aspek Terminolgi, Semantik dan Budaya." Laporan Penyelidikan. Universiti Sains Islam Malaysia, Nilai, 2006.

Zulkifli Mohamad al-Bakri. Hukum Makan Katak dan Berubat Dengannya. Kajang: Dar al-Fuqaha’, 2005. 
Jurnal Fiqh, No. 11(2014) 119-140 